\title{
Determining the Impact of Aircraft Noise towards Residential Property Price
}

\author{
Azlina Md. Yassin ${ }^{1 *}$, Mohd. Lizam Mohd. Diah ${ }^{1}$, Edie Ezwan Mohd Safian ${ }^{1}$, Mohd Yamani Yahya ${ }^{2}$, Sulzakimin Mohammad \\ \& Lim Shin Cheng ${ }^{1}$ \\ ${ }^{1}$ Department of Real Estate Management, Faculty of Technology Management and Business, University Tun Hussein Onn Malaysia \\ ${ }^{2}$ Department of Construction Management, Faculty of Technology Management and Business, University Tun Hussein Onn Malaysia
}

\begin{abstract}
The objective of this paper is to examine the effect of aircraft noise on residential property price within the case study area, and the main focus of this research was the distance of selected residential housed from Kuching International Airport (KIA). Aircraft noise is a source of noise pollution and act as environment factor that affect the house prices. Environmental disamenities from water and noise pollution will caused the houses to sell at lower price, accounted $20.8 \%$ less than houses located in area without noise interference. Apparently, the noise produced by the aircraft has even larger negative impact on house prices as compared to road traffic noise and railway noise. This study adopted quantitative approach in answering the objective of the paper. The findings were based on the secondary data which including 210 property transaction data within year 2015. The range of areas for this study was limited to selected residential terrace houses that located within $10.0 \mathrm{~km}$ from Kuching International Airport (KIA). The findings from Multiple Regression Analysis (MRA) shows that the property prices located nearer to the airport $(<2.5 \mathrm{~km}$ from KIA) in selected case study areas have been sold with lower price. Moreover, the prices of the properties located distance from KIA were not negatively impacted by the aircraft noise due to the other pulling factor that has larger impact to the property. Indeed, the location of the property, public amenities, transportation system, neighborhood factor and facilities also has close relationship to the property price.
\end{abstract}

\section{Introduction}

Property sector is one of the most important sectors in Malaysia and has significant contribution to the country's economy. Increasing number of lands have been regulated for the use of property development in order to met the market demand. Property prices especially residential property can be vary due to various factors which will also affect the buyer's purchase decision. Environmental factor is one of the important factors to consider when purchase a residential property [1]. Moreover, environment condition such as environemt pollution will cause a negative impact to the property [2]. Noise pollution was an example of negative environment condition, and generally caused from the aircraft noise, railway station, industrial sector and construction.

Moreover, environment condition such as environemt pollution will cause a negative impact to the property [2]. Noise pollution was an example of negative environment condition, and generally caused from the aircraft noise, railway station, industrial sector and construction.

However, there are arguements stated that property prices also affected by some pulling factor such as facilities, public amenities and transportation system nearby [3]. The benefits from those facilities such as airport and railway station do provide better accessibility for residents which enable them to reach the destination will lesser time and cost. At the same time the aircraft noise from the airport do also generate sound pollution to the residents nearby. Therefore, this paper aims to examine whether the residential properties price will be impacted by aircraft noise or affected by other pulling factors.

\section{Literature Review}

\subsection{Environment Pollution}

Surrounding environment quality is greatly responsible for the price and value of a property. Human looking toward for better quality of life and good environment around their property they purchase. According to [4], the values of land and property are greatly impacted by the environment quality. For home buyers, environment quality is included in their consideration factor when making decision to buy a house as it will affect the health and lifestyle of themselves and also their families. Water pollution, air pollution and noise pollution are three major environment pollutions that affect the buyer's decision when purchasing property.

\footnotetext{
Corresponding author: azlina@uthm.edu.my
} 


\subsection{Source of Sound}

Noise is a sound disturbance that unwanted by people. Noise pollution causes a big interruption into our daily activities and turn people into discomfort mode. Sound cannot be seen using visual eye but can be heard by our ears through the compression, collision or friction of waves in the air around us. Human create sound in their daily activities such as talking, singing, cooking, gardening, and so on. In this technology advance era, noise from industries, electronic gadget, machinery and engines, miscellaneous sources and transport vehicle are also the contribution to the sound and may cause sound pollution to the society.

Road noise are noise pollution that contribute a consistent state of noise which does not impact much, but the road noise resulted from rail and aircraft noise are categorized into high noise levels [5]. Noise produced when aircraft takes off or landing is one of the highest sources of noise and cause many negative health effects to human [6].

\subsection{Impact of Noise Pollution}

Noise is pervasive in our daily life and is one of the main environment pollution causing various threats and effects to human. Noise disturbance will damage sensibility to auditory stimuli of human and also causing many other consequences to human health. Some of the effect resulted from noise pollution are presented in Table 1 below.

Table 1. The Impact of Noise Pollution.

\begin{tabular}{|c|c|}
\hline Impact & Details \\
\hline Hearing impairment & $\begin{array}{l}\text { - Hearing impairment is the } \\
\text { inability of human to hear either } \\
\text { partially or totally at all. } \\
\text { - Noise pollution can cause damage } \\
\text { to hearing when a human is } \\
\text { expose to noise levels of } 80 \mathrm{~dB} \text { or } \\
\text { greater for a long period of time } \\
\text { [6]. }\end{array}$ \\
\hline Sleep disturbance & $\begin{array}{l}\text { - The major cause of sleep } \\
\text { disturbance is from the noise } \\
\text { pollution from the environment } \\
\text { [6]. } \\
\text { - The traffic noise from road } \\
\text { vehicles, railway and aircraft is } \\
\text { the main source of noise pollution } \\
\text { that mainly contributed to the } \\
\text { sleep disturbance [7]. } \\
\text { - Sleep disturbance will causes an } \\
\text { increased in blood pressure, } \\
\text { increased heart rate, rising of } \\
\text { pulse amplitude, vasoconstriction, } \\
\text { cardiac arrhythmias and } \\
\text { increasing body movement [6]. }\end{array}$ \\
\hline Annoyance & $\begin{array}{l}\text { - Annoyance is one of the side } \\
\text { effect resulted from noise } \\
\text { pollution. } \\
\text { - Noise annoyance is an unpleasant } \\
\text { feeling associated with any } \\
\text { condition from external sound } \\
\text { sources that will affect adversely }\end{array}$ \\
\hline
\end{tabular}

\begin{tabular}{|c|c|}
\hline & $\begin{array}{l}\text { to an individual or a group of } \\
\text { people. } \\
\text { - Noise annoyance might cause } \\
\text { anger, depressed, displeasure, } \\
\text { tired and stress-related symptoms. }\end{array}$ \\
\hline $\begin{array}{l}\text { Physiological } \\
\text { effects }\end{array}$ & $\begin{array}{l}\text { - Health risk has been proven } \\
\text { related with excessive and } \\
\text { continuous exposure of noise [8]. } \\
\text { - Noise act as a biological stressor } \\
\text { and long term exposure will cause } \\
\text { coronary heart disease, ulcer, high } \\
\text { blood pressure, migraine } \\
\text { headache and stress. }\end{array}$ \\
\hline $\begin{array}{l}\text { Impaired task } \\
\text { performance }\end{array}$ & $\begin{array}{l}\text { - Unwanted or unpleased noise } \\
\text { from outsource will affect the } \\
\text { worker's performance in the } \\
\text { working place [9]. } \\
\text { - Noise exposure may impact } \\
\text { performance by disturbing and } \\
\text { damaging information procession. }\end{array}$ \\
\hline
\end{tabular}

\subsection{Factors Affecting House Price in Malaysia}

Properties in Malaysia are affected by many factors. Some factors will positively impact to the property price while some factors will cause property price to drop. Factors that will affect house price in Malaysia are include location, cost of construction, government policies, Gross Domestic Product, inflation rate and environment factor.

\section{(i) Location}

Location is an important factor that will affect the property price. Different in location factor will be resulted in difference in the property value and price [10]. For example, property located nearer to the Central Business District (CBD) will be more expensive compare to property further to CBD. Clearly, factors like distance to the employment place, amenities and neighborhood factor in that particular location will also affect the property price.

\section{(ii) Cost of Construction}

Cost of construction is the total cost that used to build commercial and residential properties such as material cost, labor force, transportation cost, machinery cost, overhead cost, taxes, general expenses and the land price [11]. There is a strong correlation between the cost of construction and the selling price. For example, when a big amount of labor force are used in constructing properties, especially involved plenty of professional workers such as engineers, architects and quantity surveyors, the developer will charge the cost to the buyers which increase the selling price of the property [12]. Another research done by [13] also shows that construction cost is one of the main elements that cause the rise of property price.

\section{(iii) Government Policy}

Government policy is another factor that will cause fluctuation the house price in Malaysia. Government policy such as loans requirement for first time house buyer, reduction in tax and stamp duty, lending ability 
from financial institutional, fluctuation of interest rate and transaction fee will cause an impact to the property market. Hence, government policy on property market will cause the property price to rise up and goes down.

\section{(iv) Gross Domestic Product (GDP)}

Gross Domestic Product (GDP) is the total market value of all kind of goods and services produced in a country for a particular year. GDP is considered as an indicator for property sector because of the relationship between macroeconomic activity and the price of property [14]. Research conducted by [15] indicates that there is significant and positive correlation between GDP and the house price in Malaysia. Indeed, rising up in property purchasing and investment will bring along the increasing house price and also the growth of GDP.

\section{(v) Inflation Rate}

When the supply of money in the market expands, interest rates will drop and higher and easier creditability will be able to obtain. This situation will triggers spending and increases the demand for goods and service. However, at a point when additional increase in the money supply will stimulate demand overtake the ability of the current economy to increase supply. This will cause the result in inflation. Inflation is the rising in the price of goods and services in a economy country. When everything in the economy tend to increase in price, which include the construction cost such as labor force and raw materials cost, the cost for a building will also increase and resulted in rising of selling price of the property [15]. In that case, all type of properties such as commercial, residential and industrial properties will be affected by the inflation rate of the country.

\section{(vi) Environmental Factor}

The condition of environment will capitalized in the property value and price [2]. The surrounding development will have either positive or negative impact towards the property value and price nearby. Until today there are still arguments on the environment factor that will positively or negatively affect the property price. Individual that lives in house located near public facilities or amenities may enjoy the benefits and convenience for the facilities, but at the same time they may also suffer from the impact produced by those facilities such as pollution. When the environment disamenities has larger negative impact to the property, the demand for the housing in that particular area will be decrease, and cause an reduce in property selling price or increase of the discount rate.

However, there are arguments on the effects of environment condition on different property sub-sectors. Research done by [16] indicate that railway station has positive effect to the nearby residential property. The research also proved that railway station function as transport network has larger positive effect to commercial property that located nearby compare to residential property. Hence, the environment factor can either positively or negatively effects on different property sub-sectors.

\section{Research Methodology}

In this study, a quantitative research strategy was adopted as a strategy for the data collection. The data for this research was the sales transaction data of property from Valuation and Property Services Department (JPPH) in Kuching, Sarawak. Finally, 210 sales transaction data were gathered as an evidence to support in answering research objective which aimed to examine the effect of aircraft noise on residential property price within study area. The research area compromise some selected residential areas in Kuching with distance 2.5 kilometers, 5.0 kilometers, 7.5 kilometers and 10 kilometers from the airport and the airport act as the central point.

\section{Research Findings and Discussion}

\subsection{Sales Transaction Data}

Sales transaction data have been collected from Valuation and Property Services Department, Kuching. A total of 210 transaction data were collected and all the transactions were happened in year 2015. The transaction data only included one type of housing only which was terrace house in order to make comparison of house price with different distance from the Kuching International Airport (KIA). The range of study areas for this research was limited to selected residential terrace houses that located within $10.0 \mathrm{~km}$ from Kuching International Airport (KIA).

Furthermore, all 210 transaction data were categorized into different areas according to the distance from Kuching International Airport (KIA). There were total four groups of distance has been divided, which were less than $2.5 \mathrm{~km}$ (Distance A), 2.5-5.0 km (Distance B), 5.1-7.5 km (Distance C) and 7.6-10.0 km (Distance D).

\subsection{The Impact of Aircraft Noise on Residential Property Price}

In the Multiple Regression Analysis, there were five predictor variables which include tenure, type of building, size of building, number of room and distance of living area from Kuching International Airport (KIA). All the VIF values in range between 1 to 10 and the highest value shown were 6.036. In this case, there is no significant evidence of multicollinearity and thus multicollinearity between predictor variables did not exist.

In term of the effect of distance of selected residential houses from Kuching International Airport (KIA) towards residential house price, the result shows that the significant level of leasehold tenure was 0.072 and the beta coefficient was negative 23090.883 . The pvalue of leasehold tenure proved that the selected house price with leasehold tenure was not significant compare to selected house price with freehold tenure. 
The type of building also categorized into three types, intermediate terrace house, side terrace house and corner lot terrace house. From the analysis, the significant levels for both side and corner lot terrace houses were 0.530 and 0.000 . Meanwhile, the beta coefficients for both side and corner lot terrace house were 20265.337 and 57050.209. The result indicates that side terrace houses have similar price compare to intermediate terrace house. Corner lot terrace house have significant $\mathrm{p}$-value which shows higher price compare to intermediate terrace house. The results were reliable with the theory of housing as houses located at corner have more privacy space and building size. The extra benefits of corner lot terrace house resulted in higher price.

Significant level for building size was 0.000 and beta coefficient was 2527.607 whereas for number of rooms was 0.201 with beta coefficient of 18455.571 . As the size of the building increase, the house price also increase as compare with similar properties. Majority of the selected terrace houses have 3 rooms and only few of the selected property have 2 and 4 rooms. The result shows that the number of rooms has no major effect to the price of selected residential properties.

The main focus of this research was the distance of selected residential houses from Kuching International Airport (KIA). From the findings, significant level of Distance B, Distance C and Distance D were significant. The significant levels for three group distances were $0.016,0.016$ and 0.009 . The beta coefficients for three group distance B,C and D were 73302.200, 76123.699 and 83992.167. If the p-value was less than the significant value or $p<0.05$, then the null hypothesis must be rejected. However, if the p-value is larger than significant value or $\mathrm{p}>0.05$, then the null hypothesis will be accepted. Hence, the null hypothesis for three group distances must to rejected and the alternative hypothesis will be accepted. Both group Distance B, Distance C and Distance D have significant price difference compare to group Distance A. The B-coefficient value for group Distance B, Distance C and Distance D were positive compare to Distance and the values were increasing with the increasing of distance from Kuching International Airport (KIA). Hence, there was obvious evidence

\section{Conclusion}

The objective of this paper is to examine the effect of aircraft noise from Kuching International Airport (KIA) on selected residential property price. The findings from the analysis showed that the distance of residential property from Kuching International Airport have insignificant relationship with their property price. Although the house price of selected residential properties were lower in distance less than $2.5 \mathrm{~km}$ compared to other distance, but the inconsistency increasing of beta coefficient value of other group distances shows that distance of selected residential house price was not the main factor that affects the house price.

Moreover, the results found out there was other factors that affected the residential property price. Factor like type of the building such as intermediate lot or corner lot and building size has an effect to the residential property price. It was a fact that the price of the property was evaluated with the price for a square meter. Besides that, even though some of the properties were located at the same area, the location of the properties such as corner lot or intermediate lot also affected the property price.

This applied with the theory of housing as houses located at corner have more privacy space and building size. The extra benefits on space and privacy of corner lot terrace house resulted in higher price. The prices of the properties located in group Distance B, C and D were not negatively impacted by the aircraft noise due to the other pulling factor that has larger impact to the property. There were other unobserved variables that mainly affect the house price, namely the location of the property, public amenities, transportation system, neighbourhood factor and facilities also has close relationship to the property price.

Thus, the noise pollution from aircraft noise was not the main factor that affects the selected residential property price.

We are grateful for the RMC, UTHM for the publication opportunity and Ministry of Higher Education for the Fundamental Research Grant Scheme (FRGS).

\section{References}

1. S. L. Sean, \& T.H. Tan, T, Factors Affecting the Purchase Decision of Investors in the Residential Property Market in Malaysia. Journal of Surveying, Construction and Property, 5(2). 1-13, (2014).

2. A. Hamid, N. Hamidi \& L. Shamree, The effects Of environmental disamenities on house prices. Malaysian Journal of Real Estate, 4(2), 31-44, (2009).

3. P. Manivannan \& M. Somasundaram, Purchase of Residential Flats-Factor Influencing the Decision of Buyers in Selected Cities in Tamil Nadu. International Research Journal of Business and Management, 7(9), 67-73, (2014).

4. C. O. Oloke, F.R. Simon \& A.F. Adesulu, An Examination of the Factors Affecting Residential Property Values in Magodo Neighbourhood, Lagos State. International Journal of Economy,Management and Social Sciences, 2(8), 639-643, (2013).

5. V. B. Omubo-Pepple, M. A. Briggs-Kamara \& I. Tamunobereton-ari Noise Pollution in Port Harcourt Metropolis: Sources, Effects and Control. The Pacific Journal of Science and Technology, 11(2), 592-600, (2010).

6. P. A. Savale, Effect of noise pollution on human being: Its prevention and control. Journal of Environmental Research and Development, 8(4), 1026-1036 (2014).

7. H. Niemann \& C. Maschke, WHO LARES Final report Noise effects and morbidity. Berlin: World Health Organisation, t1. (2004) 
8. M. M. Anees, M. Qasim \& A. Bashir, Physiological and Physical Impact of Noise Pollution On Environment. Asian Journal of Environmental and Earth Sciences, 1(1), 25-31, (2014)

9. S. A. Stansfeld, B. Berglund, C. Clark, I. LopezBarrio, P. Fischer, E. Öhrström, M. M. Haines, J. Head, S. Hygge, I. Kamp \& B. F. Berry, Aircraft and Road Traffic Noise and Children's Cognition and Health: A Crossnational Study. The Lancet, 365(9475), 1942-1949, (2005).

10. D. Maclennan \& M. Munro, Urban Housing Price Change: Glasgow 1974 1984. Housing Studies, 2, 238-260, (1987).

11. N. A. Haron, H. Salihuddin, M.A. Razali \& M.J. Saleh, Building Cost Comparison Between Conventional and Formwork System. Journal Technology, 43(B) , 1-11. (2005)

12. B. A. Smith \& W.P. Tesarek, House Prices and Regional Real Estate Cycles: Market Adjustment in Houston. Journal of the American Real Estate and Urban Economic Association, 19, 396-416, (1991)

13. N. A. Haron \& C. Liew, Factors Influencing the Rise of House Price in Klang Valley. International Journal of Research in Engineering and Technology,2(10), 261-272, (2013).

14. M. Wheeler \& A.R. Chowdhury, The Housing Market, Macroeconomic Activity And Financial Innovation: An Empirical Analysis Of US Data. Journal of Applied Economics, 25(3), 385-392, (1993).

15. T. S. Ong, Factors Affecting The Price Of Housing In Malaysia. Journal of Emerging Issues in Economics, Finance and Banking, 1(5), 414-429, (2013).

16. G. Debrezion, E. Pels \& P. Rietveld, The Impact of Railway Stations on Residential and Commercial Property Value: A Meta-Analysis. The Journal of Real Estate Finance and Economics, 35(2), 161180,(2007 